\title{
A Double Whammy: A Case Report and Review of the Literature on Pneumococcal Coinfection in COVID-19 Patients
}

\author{
Lubaina Ibrahim ${ }^{1}$, Lokesh Manjani ${ }^{1}$, Ahmad Nassar ${ }^{2}$, Aleena R. Mahmood ${ }^{1}$, Hussam Ammar ${ }^{2}$ \\ 1. Medicine, MedStar Washington Hospital Center, Washington, DC, USA 2. Internal Medicine, Medstar Washington \\ Hospital Center, Washington, DC, USA
}

Corresponding author: Hussam Ammar, hussam.ammar@medstar.net

\begin{abstract}
Bacterial coinfections which are infections present early in the course of coronavirus disease 2019 (COVID19) infections before hospitalizations during the 2020 pandemic are rare. A 66-year-old male presented to the ED with a two-week history of subjective fever, dyspnea, and productive cough. He was diagnosed with coinfection of severe COVID-19 pneumonia and pneumococcal infection. He recovered from both infections and was discharged home. This report presents the features of this case and reviews the literature of similar cases of coinfection of COVID-19 pneumonia and pneumococcal infection.
\end{abstract}

Categories: Internal Medicine, Medical Education, Infectious Disease

Keywords: covid-19, streptococcus pneumoniae, coinfection, pneumococcal infection, pneumonia

\section{Introduction}

Bacterial coinfections which are infections present early in the course of respiratory viral infections before hospitalizations are a leading cause of severe morbidity and mortality, especially among high risk groups such as the elderly [1]. Recent re-analysis of post-mortem lung cultures from 1918 influenza pandemic showed evidence of bacterial infection in $>90 \%$ of specimens [1]. The rate of bacterial coinfection during the 2020 COVID-19 pandemic is lower than the rate of bacterial coinfection during the 1918 influenza H1N1 and 2009 influenza H1N1 pandemics [1-2]. This report presents a rare case of coinfection of COVID19 pneumonia and pneumococcal infection in a 66-year-old man. The report also reviews the clinical features, radiological findings, and outcomes of cases of coinfection of COVID-19 pneumonia and pneumococcal infection in the English literature.

\section{Case Presentation}

A 66-year-old male presented to the ED with a two-week history of subjective fever, dyspnea, and a productive cough of rusty sputum. The symptoms started insidiously and improved after a few days of onset only to progressively worsen, bringing the patient to the hospital. The patient has a past medical history of diabetes mellitus (DM), chronic kidney disease (CKD), hypertension (HTN), coronary artery disease, and heart failure with preserved ejection fraction. On initial exam, he was tachypneic with a respiratory rate of 32 breaths $/ \mathrm{min}$, febrile with a temperature of $39.7^{\circ} \mathrm{C}$, pulse rate of 101 beats/min, and blood pressure of $146 / 84 \mathrm{mmHg}$, and he required $15 \mathrm{~L}$ of oxygen/min through a nonrebreather mask to maintain his oxygen saturation above $94 \%$. Lung auscultation was significant for crackles at lung bases bilaterally. Chest radiograph at presentation showed bilateral patchy basal infiltrates (Figure 1). 


\section{Cureus}

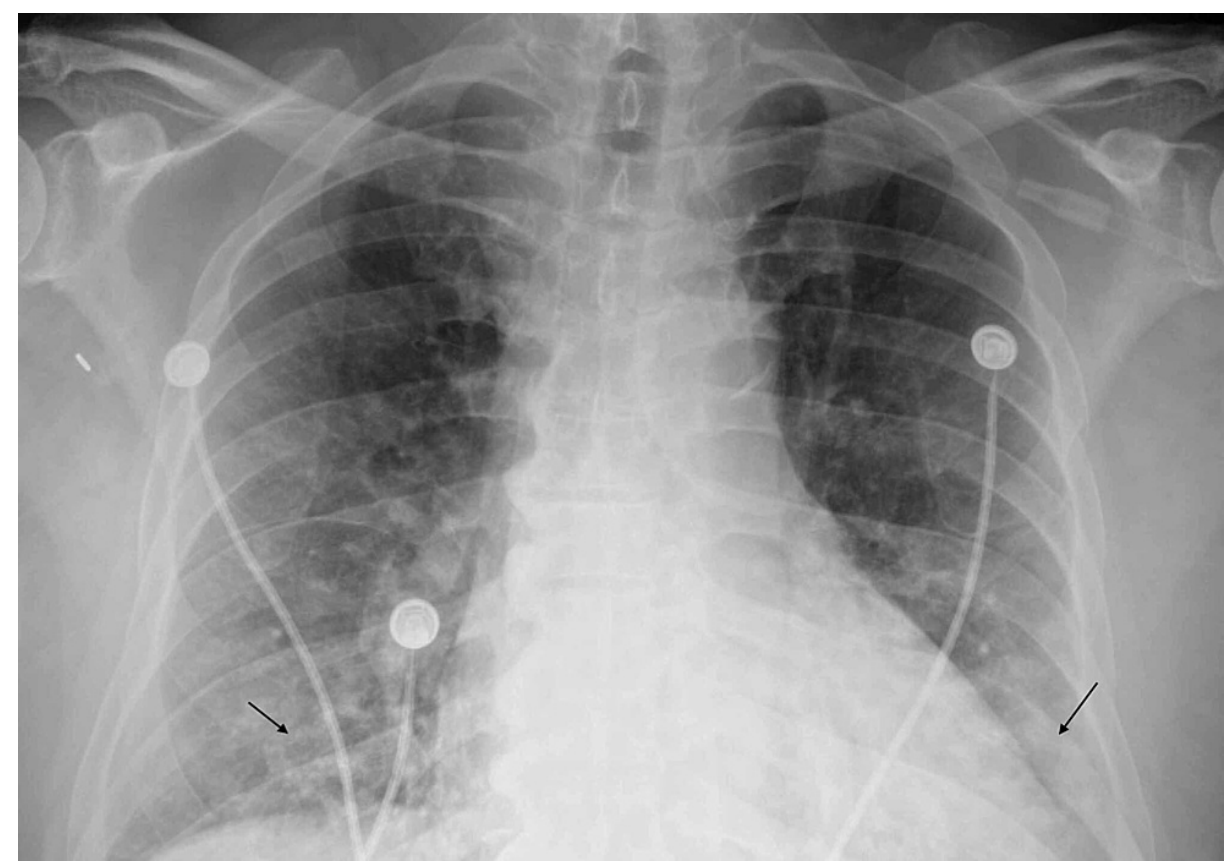

\section{FIGURE 1: Chest radiography.}

Bilateral patchy basal infiltrates "arrows" on admission CXR

CXR, chest X-ray

Laboratory work was significant for a creatinine level of $1.76 \mathrm{mg} / \mathrm{dL}$, and the white blood cell count was 6,300 cells per cubic per millimeter with an absolute lymphocyte count of 1,800 cells per cubic millimeter, Creactive protein of $143 \mathrm{mg} / \mathrm{L}$, fibrinogen of $1026 \mathrm{mg} / \mathrm{dL}$, D-dimer of $11.6 \mathrm{mcg} / \mathrm{mL}$, and ferritin of 1071 ng/mL. Nasal swab for COVID-19 polymerase chain reaction (PCR) was positive. The patient was admitted to general medicine service; he received a loading dose of IV remdesivir $200 \mathrm{mg}$ followed by $100 \mathrm{mg}$ IV daily for five days. IV dexamethasone $6 \mathrm{mg}$ daily was given for 10 days.

The admitting physician suspected cobacterial infection because of the history of rusty sputum and administered ceftriaxone $2 \mathrm{~g}$ IV for five days upon admission to general medicine. Urine Streptococcal pneumoniae antigen was reported to be positive a few hours after his admission. Blood culture revealed no growth, and chest CT performed two days after admission revealed bilateral consolidative infiltrates (Figure 2). 


\section{Cureus}

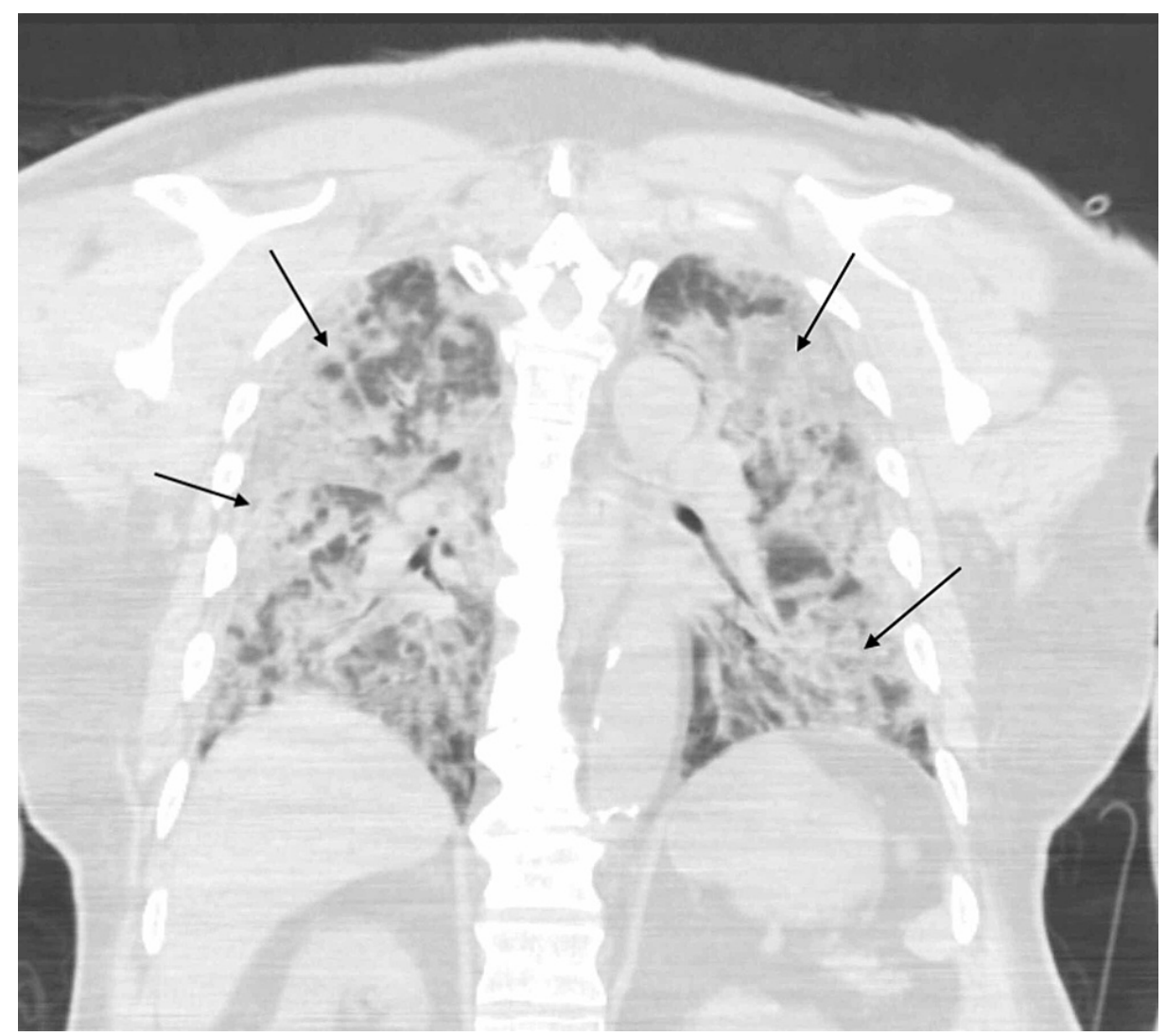

FIGURE 2: Chest CT scan.

Bilateral consolidative infiltrates " arrows " on a follow up CT chest 48 hours after admission

Respiratory status improved slowly; he required $10 \mathrm{~L}$ of oxygen/min on day 5 and $5 \mathrm{~L}$ of oxygen/min on day 7 when he developed severe chest pain, which improved with nitroglycerine. An electrocardiogram revealed subtle ST segment depression in lead 3, and high sensitivity troponin I was elevated at 33.048 ng/L. An echocardiogram revealed an ejection fraction of $45 \%$ and hypokinetic anterior and lateral walls. Non-ST segment elevation myocardial infarction was diagnosed and managed conservatively with aspirin,

clopidogrel, metoprolol, heparin, and atorvastatin with a plan for heart catheterization a few weeks after he recovered from his illness. The patient also developed acute kidney injury with a peak creatinine of 2.8 $\mathrm{mg} / \mathrm{dL}$, which recovered on conservative management to a baseline creatinine of $1.5 \mathrm{mg} / \mathrm{dL}$. He also received a few doses of furosemide. He did not require intensive care admission, and his oxygen saturation was $98 \%$ on ambient air on day 10 but dropped to the low eighties with ambulation. He was discharged home on day 12 with home oxygen to be used with ambulation. Our patient had a follow up in the medicine clinic two weeks after his discharge, and he was very pleased that he recovered from COVID-19.

\section{Discussion}

Respiratory viral infections predispose patients to bacterial coinfections, which lead to increased severity and mortality [1]. Bacterial pneumonia caused the majority of deaths during the 1918-1919 influenza pandemic [1]. The rate of bacterial coinfection in hospitalized influenza patients during the $2009 \mathrm{H} 1 \mathrm{~N} 1$ influenza pandemic was 19\% [3]. A recent review and meta-analysis that included 24 studies and defined coinfection as infection present at presentation and secondary infection as infection acquired during hospital stay, reported a rate of $3.5 \%$ for coinfection and a rate of $14.3 \%$ for secondary infection in July 2020 [2]. The current rate as of December 2020 is $4.6 \%$ and $16 \%$ for coinfection and secondary infection, respectively [4]. Mycoplasma species, Hemophilus influenza, and Pseudomonas infection were the most common bacterial isolates. Case reports and case series were excluded from this meta-analysis [2, 4]. Streptococcus pneumoniae is identified in $10 \%-15 \%$ of cases of community-acquired pneumonia [5].

Our literature search found 19 cases (Table 1 ) with a description of cases of coinfection with S. pneumoniae and COVID-19 that were published in four reports from Spain, the UK, and the USA [6-9]. We excluded two patients from the Spanish report, as the diagnosis of COVID-19 was based on radiological diagnosis and never confirmed with PCR [7]. 


\begin{tabular}{|c|c|c|c|c|c|c|c|}
\hline Study & Age & $\begin{array}{l}\text { Symptoms on } \\
\text { presentation }\end{array}$ & Comorbidities & Radiological findings & $\begin{array}{l}\text { Diagnosis of } \\
\text { Streptococcus } \\
\text { pneumoniae }\end{array}$ & $\begin{array}{l}\text { Length } \\
\text { of stay }\end{array}$ & Outcome \\
\hline $\begin{array}{l}\text { Toombs et } \\
\text { al. [6] UK }\end{array}$ & 86 & $\begin{array}{l}\text { Dyspnea, fever, } \\
\text { fatigue }\end{array}$ & $\begin{array}{l}\text { Alzheimer's disease, HTN, } \\
\text { and disseminated } \\
\text { malignancy }\end{array}$ & $\begin{array}{l}\text { Bilateral interstitial } \\
\text { infiltrate }\end{array}$ & Blood culture & $\begin{array}{l}15 \\
\text { days }\end{array}$ & Death \\
\hline $\begin{array}{l}\text { Toombs et } \\
\text { al. [6] UK }\end{array}$ & 82 & $\begin{array}{l}\text { Chest pain, fever, } \\
\text { and cough }\end{array}$ & $\begin{array}{l}\text { DM, ischemic } \\
\text { cardiomyopathy, HTN, and } \\
\text { CKD }\end{array}$ & $\begin{array}{l}\text { Bilateral patchy } \\
\text { consolidation }\end{array}$ & Blood culture & $\begin{array}{l}21 \\
\text { days }\end{array}$ & Discharged \\
\hline $\begin{array}{l}\text { Cucchiari et } \\
\text { al. [7] Spain }\end{array}$ & 86 & $\begin{array}{l}\text { Fever, cough, } \\
\text { dyspnea }\end{array}$ & $\begin{array}{l}\text { DM, HTN, ischemic } \\
\text { cardiomyopathy, CKD, } \\
\text { aortic stenosis }\end{array}$ & $\begin{array}{l}\text { Unilateral consolidative } \\
\text { infiltrates }\end{array}$ & $\begin{array}{l}\text { Pneumococcal } \\
\text { urine antigen }\end{array}$ & NA & Discharged \\
\hline $\begin{array}{l}\text { Cucchiari et } \\
\text { al. [7] Spain }\end{array}$ & 65 & $\begin{array}{l}\text { Fever, cough, } \\
\text { dyspnea, diarrhea }\end{array}$ & Depression & $\begin{array}{l}\text { Bilateral interstitial } \\
\text { infiltrate }\end{array}$ & $\begin{array}{l}\text { Pneumococcal } \\
\text { urine antigen }\end{array}$ & NA & Discharged \\
\hline $\begin{array}{l}\text { Cucchiari et } \\
\text { al. [7] Spain }\end{array}$ & 44 & $\begin{array}{l}\text { Fever, Cough, } \\
\text { Hyposmia Dysgeusia } \\
\text { Arthromyalgia }\end{array}$ & DM, Obesity, asthma & $\begin{array}{l}\text { Bilateral interstitial } \\
\text { infiltrates }\end{array}$ & $\begin{array}{l}\text { Pneumococcal } \\
\text { urine antigen }\end{array}$ & NA & Discharged \\
\hline $\begin{array}{l}\text { Rodriguez- } \\
\text { Nava et al. } \\
\text { [9], USA }\end{array}$ & 92 & $\begin{array}{l}\text { Fever, dyspnea, } \\
\text { myalgia, altered } \\
\text { mental status }\end{array}$ & HTN, DM, hyperlipidemia & Unilateral infiltrates & NA & 5 days & Discharged \\
\hline $\begin{array}{l}\text { Rodriguez- } \\
\text { Nava et al. } \\
\text { [9], USA }\end{array}$ & 82 & Cardiac arrest & $\begin{array}{l}\mathrm{HTN}, \mathrm{DM} \text {, atrial fibrillation, } \\
\text { asthma, dementia }\end{array}$ & Bilateral infiltrate & NA & 7 days & Death \\
\hline $\begin{array}{l}\text { Roariguez- } \\
\text { Nava et al. } \\
\text { [9], USA }\end{array}$ & 75 & $\begin{array}{l}\text { Dyspnea, altered } \\
\text { mental status }\end{array}$ & $\begin{array}{l}\text { Stroke, OSA, seizure, } \\
\text { hyperlipidemia }\end{array}$ & Unilateral infiltrate & NA & 7 days & Death \\
\hline $\begin{array}{l}\text { Rodriguez- } \\
\text { Nava et al. } \\
\text { [9], USA }\end{array}$ & 77 & Dyspnea, lethargy & $\begin{array}{l}\text { HTN, deep venous } \\
\text { thrombosis, COPD, } \\
\text { supraventricular } \\
\text { tachycardia }\end{array}$ & Bilateral infiltrates & NA & 2 days & Death \\
\hline $\begin{array}{l}\text { Roariguez- } \\
\text { Nava et al. } \\
\text { [9], USA }\end{array}$ & 81 & $\begin{array}{l}\text { Dyspnea, fever, } \\
\text { cough, chills }\end{array}$ & $\begin{array}{l}\text { DM, COPD-asthma, } \\
\text { hyperlipidemia }\end{array}$ & Bilateral infiltrates & NA & 6 days & Death \\
\hline $\begin{array}{l}\text { Rodriguez- } \\
\text { Nava et al. } \\
\text { [9], USA }\end{array}$ & 74 & Dyspnea, lethargy & HTN, dementia & Bilateral infiltrates & NA & $\begin{array}{l}19 \\
\text { days }\end{array}$ & Death \\
\hline $\begin{array}{l}\text { Rodriguez- } \\
\text { Nava et al. } \\
\text { [9], USA }\end{array}$ & 90 & Fatigue & HTN, DM & Unilateral infiltrate & NA & 7 days & Discharged \\
\hline $\begin{array}{l}\text { Rodriguez- } \\
\text { Nava et al. } \\
\text { [9], USA }\end{array}$ & 74 & $\begin{array}{l}\text { Fever, dyspnea, } \\
\text { altered mental } \\
\text { status, fatigue }\end{array}$ & $\begin{array}{l}\text { HTN, Parkinson, } \\
\text { hypothyroidism }\end{array}$ & Bilateral infiltrates & NA & 8 days & Death \\
\hline $\begin{array}{l}\text { Rodriguez- } \\
\text { Nava et al. } \\
\text { [9], USA }\end{array}$ & 72 & $\begin{array}{l}\text { Dyspnea, fever, } \\
\text { lethargy }\end{array}$ & COPD, dementia, HTN & Unilateral infiltrates & NA & 6 days & Death \\
\hline $\begin{array}{l}\text { Nava et al. } \\
\text { [9], USA }\end{array}$ & 82 & $\begin{array}{l}\text { Altered mental } \\
\text { status, anorexia }\end{array}$ & HTN, dementia & Unilateral infiltrates & NA & 6 days & Death \\
\hline $\begin{array}{l}\text { Rodriguez- } \\
\text { Nava et al. } \\
\text { [9], USA }\end{array}$ & 74 & $\begin{array}{l}\text { Dyspnea, cough, } \\
\text { and fever }\end{array}$ & DM, COPD, stroke, HTN & Bilateral infiltrates & NA & $\begin{array}{l}21 \\
\text { days }\end{array}$ & Discharged \\
\hline $\begin{array}{l}\text { Pal et al. [8] } \\
\text { USA }\end{array}$ & 51 & $\begin{array}{l}\text { Alcohol intoxication, } \\
\text { right pleuritic chest }\end{array}$ & $\begin{array}{l}\text { Emphysema, human } \\
\text { immune deficiency virus }\end{array}$ & $\begin{array}{l}\text { CT scan bilateral ground } \\
\text { glass and right middle }\end{array}$ & Sputum culture & 8 days & Discharged \\
\hline
\end{tabular}




\section{Cureus}

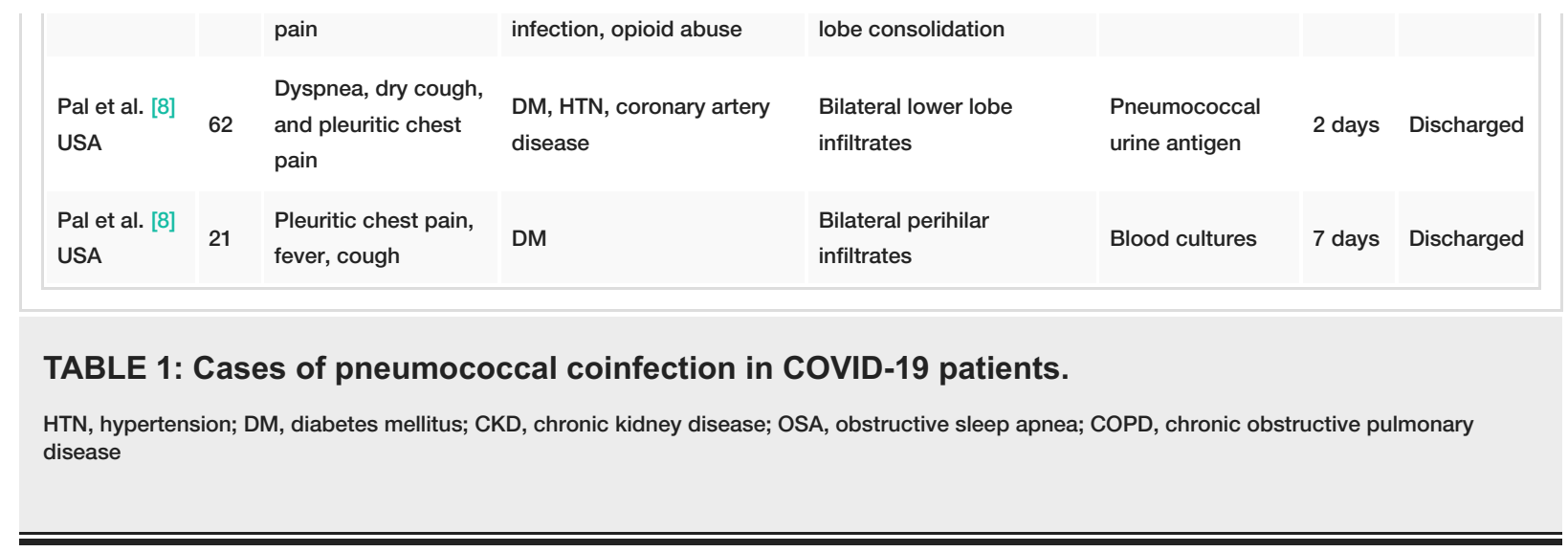

The patient in this report was 66 years old, the median age for cases in our literature review was 75 years, and the ages ranged from 21 to 92 . Four patients (21\%) presented with fever, cough and dyspnea, similar to our patient. There was no description of the quality of cough as described in our report except in one patient who had a dry cough. The rusty sputum in this case was the single finding that prompted the initiation of antibiotics, and it has historically been thought to be a classic feature of pneumococcal pneumonia [10]. One study showed that rusty sputum has a positive predictive value of $23 \%$ for positive Gram staining and culture; S. pneumoniae did not grow in any patient with rusty sputum but grew from yellow green and green and creamy sputum samples [10]. Productive cough is not a unique finding for bacterial pneumonia, as it was present in approximately $50 \%$ of patients with COVID-19 in one report [11].

Fever and dyspnea were the most common symptoms identified from the literature review, and each was present in 11 patients (58\%), while chest pain and altered mental status were present in four patients (21\%). The median number of comorbidities for the patients in the literature search was three, and the patient presented in this case had five comorbidities. Hypertension was the most common comorbidity and was found in 13 (68\%) patients, while diabetes was the second most common comorbidity and was present in 11 (52.6\%) patients.

Bilateral infiltrates were the most common radiological findings in this series and were present in 13 (68\%) patients. Unilateral infiltrates were present in six (31.5\%) patients. A detailed description of the type of infiltrates was present in only seven cases: one case with lower lobe infiltrates, another case with perihilar infiltrates, three cases with bilateral interstitial infiltrates, and two cases with consolidative infiltrates. The patient in this case presented initially with bilateral patchy basal infiltrates that progressed in two days to bilateral consolidative infiltrates on chest CT. These findings overlap with the radiological findings of pneumococcal pneumonia, and the classic radiologic feature of S. pneumoniae is a consolidative lobar disease [12]. In one study of 40 patients with S. pneumoniae, 12 patients had a consolidative appearance, 12 patients had a patchy "bronchopneumonia" pattern, 9 patients had an interstitial pattern, and 7 patients had a mixed appearance [12]. Nine patients (47\%) died in this series, and the overall 30-day mortality rate of hospitalized pneumococcal community-acquired pneumonia was $8 \%$ [13]. The mortality rate of hospitalized COVID-19 patients dropped from 25.6\% in March to 7.6\% in August 2020 [14].

\section{Conclusions}

Streptococcus pneumoniae coinfection should be considered in patients with COVID-19 pneumonia with multiple comorbidities and advanced age. There are no published North American guidelines on the role of empiric antibiotics in patients with COVID-19 pneumonia. Patients should be evaluated on individual basis for the possibility of bacterial coinfection, and if antibiotics are to be initiated, re-evaluation in two to three days is needed to discontinue or adjust antibiotics based on the case progress and results of microbiological tests.

\section{Additional Information \\ Disclosures}

Human subjects: Consent was obtained or waived by all participants in this study. Conflicts of interest: In compliance with the ICMJE uniform disclosure form, all authors declare the following: Payment/services info: All authors have declared that no financial support was received from any organization for the submitted work. Financial relationships: All authors have declared that they have no financial relationships at present or within the previous three years with any organizations that might have an interest in the submitted work. Other relationships: All authors have declared that there are no other relationships or activities that could appear to have influenced the submitted work.

\section{References}

1. Joseph C, Togawa Y, Shindo N: Bacterial and viral infections associated with influenza . Influenza Other 
Respir Viruses. 2013, 7:105-113. 10.1111/irv.12089

2. Langford BJ, So M, Raybardhan S, et al.: Bacterial co-infection and secondary infection in patients with COVID- 19: a living rapid review and meta-analysis. Clin Microbiol Infect. 2020, 26:1622-1629. 10.1016/j.cmi.2020.07.016

3. MacIntyre CR, Chughtai AA, Barnes M, Ridda I, Seale H, Toms R, Heywood A: The role of pneumonia and secondary bacterial infection in fatal and serious outcomes of pandemic influenza a(H1N1)pdm09. BMC Infect Dis. 2018, 18:637. 10.1186/s12879-018-3548-0

4. Bacterial co-infection and secondary infection in patients with COVID- 19: a living rapid review and metaanalysis. (2020). Accessed: December 26, 2020: https://www.tarrn.org/covid.

5. Musher DM, Abers MS, Bartlett JG: Evolving understanding of the causes of pneumonia in adults, with special attention to the role of pneumococcus. Clin Infect Dis. 2017, 65:1736-1744. 10.1093/cid/cix549

6. Toombs JM, Van den Abbeele K, Democratis J, Mandal AKJ, Missouris CG: Pneumococcal coinfection in COVID-19 patients. J Med Virol. 2021, 93:177-179. 10.1002/jmv.26278

7. Cucchiari D, Pericàs JM, Riera J, Gumucio R, Md EC, Nicolás D, Clínic HTH: Pneumococcal superinfection in COVID-19 patients: a series of 5 cases. Med Clin. 2020, 155:502-505. 10.1016/j.medcli.2020.05.022

8. Pal C, Przydzial P, Chika-Nwosuh O, Shah S, Patel P, Madan N: Streptococcus pneumoniae coinfection in COVID- 19: a series of three cases. Case Rep Pulmonol. 2020, 2020:8849068. 10.1155/2020/8849068

9. Rodriguez-Nava G, Yanez-Bello MA, Trelles-Garcia DP, Chung CW, Egoryan G, Friedman HJ: A retrospective study of coinfection of SARS-CoV-2 and streptococcus pneumoniae in 11 hospitalized patients with severe COVID-19 pneumonia at a single center. Med Sci Monit. 2020, 26:928754.

10. Johnson AL, Hampson DF, Hampson NB: Sputum color: potential implications for clinical practice . Respir Care. 2008, 53:450-454.

11. Xu XW, Wu XX, Jiang XG, et al.: Clinical findings in a group of patients infected with the 2019 novel coronavirus (SARS-Cov-2) outside of Wuhan, China: retrospective case series. BMJ. 2020, 368:606. 10.1136/bmj.m606

12. Kantor HG: The many radiologic facies of pneumococcal pneumonia . Am J Roentgenol. 1981, 137:12131220. 10.2214/ajr.137.6.1213

13. Cillóniz C, Liapikou A, Martin-Loeches I, et al.: Twenty-year trend in mortality among hospitalized patients with pneumococcal community-acquired pneumonia. PLoS One. 2018, 13:0200504. 10.1371/journal.pone.0200504

14. Horwitz LI, Jones SA, Cerfolio RJ, Francois F, Greco J, Rudy B, Petrilli CM: Trends in COVID-19 risk-adjusted mortality rates . J Hosp Med. 2020, 10.12788/jhm.3552 